\title{
Infection to Recovery; COVID-19 in Pakistan and its Implications
}

\author{
Sadia Zia (D) \\ Department of Biotechnology, Faculty of Life Sciences, University of Central Punjab, Lahore, Pakistan \\ ${ }^{\star}$ Corresponding author: Email: sadia.zia@ucp.edu.pk
}

(Received 19 June 2020; Revised 20 July 2020; Accepted 23 July 2020)

\begin{abstract}
The New pandemic is hitting all around the world in different manner. The infection rate, prevalence and severity is not patronized in many countries. Pakistan is now attaining the peak in its cases. Around 108,317 confirmed cases are present in Pakistan and 71,127 are currently active cases1. The recovery rate is $32 \%$. The dangerous situation about the infection prevalence is that most of the people either are asymptomatic of having mild symptoms. An estimation release from Primary Health Department of Punjab claims that almost 670,000 cases are asymptomatic in only Lahore city 2 . This correspondence is about an infected family of 5 people 3 males and 2 females in Lahore, Pakistan. Who were exposed with virus and one after one got the infection, the two males deceased but rest of family member are recovered.
\end{abstract}

The New pandemic is hitting all around the world in different manner. The infection rate, prevalence and severity is not patronized in many countries. Pakistan is now attaining the peak in its cases. Around 108,317 confirmed cases are present in Pakistan and 71,127 are currently active cases (Ministry of Health, Government of Pakistan, n.d.). The recovery rate is $32 \%$. The dangerous situation about the infection prevalence is that most of the people either are asymptomatic of having mild symptoms. An estimation release from Primary Health Department of Punjab claims that almost 670,000 cases are asymptomatic in only Lahore city (Primary and Secondary Health Care Department, n.d.). This correspondence is about an infected family of 5 people 3 males and 2 females in Lahore, Pakistan. Who were exposed with virus and one after one got the infection, the two males deceased but rest of family member are recovered. The particular family is depicted the story of mostly reported cases in Pakistan. There are 3 major factors which are prevailing and causing death toll near 2172 (Ministry of Health, Government of Pakistan, n.d.).

In Pakistan, Infection is more prevalent to Men as compared to Women, secondly, Co-morbidity is clear; those patients who are already suffering from Cardiovascular and Respiratory diseases, thirdly anemic and iron deficient patients are more at risk. According to Histopathological Reports Most of the patients experienced the low $\mathrm{Hb}$ level, low zinc level and vitamin A and D deficiency.

This observatory is about 5 patients who felt the mild symptoms of COVID-19 like fever and itching in throat after attending the funeral of a relative. The physician suggested them to get COVID-19 PCR based test which came detected. Within 7 days' patients felt severe itching in throat and de-hydration during isolation at home. Meanwhile the RT-PCR tests were with mild symptoms like fever, sore throat and their physician recommended them to keep in isolation and prescribe the following measures for first 5 days; 
Azithromycin (Zetro), Montelukast sodium Tablet (Flaoid), Ascard $75 \mathrm{mg}$, Vitamin C supplements and Steam inhalation. This prescription is standard and use all over the Pakistan. During the 5 days' patients kept isolated at home and getting steam inhalation along with medications. The patients were told to do mild breathing exercises and kept their record of oximeter readings. The patient ARF on 7th day got severe coughing and pulse oximeter reading went to 65 with BP 108/70 and got hospitalized. On 8th day the patients transferred to Ventilator and 2 (males)of them got expired.

it was observed in most of the patients with age range of 25 years - 40 years to be recovered on 15 th day with negative RT-PCR report. Till now, the recovery rate in Pakistan is slightly good as usually patients feel less symptoms on day 10 th. Still Pakistan is facing test positivity rate at $24 \%$. There is capacity to perform 20, 000 PCR tests on daily basis in local hospitals. Other main factors for declaring 4rth most dangerous country for COVID-19 infection are; poverty, economical disequilibrium, lack of knowledge, unwillingness of people to cooperate with government policies, and early ease in lockdown by Government.

In a letter to the Punjab Health Minister Pakistan, the UN health agency said that the virus had spread all over the country, and a large number of cases had been recorded in big cities. The cases had increased sharply after the ease of lockdown. Due to this, Pakistan ranks among top-10 most affected countries.

The letter appreciated the Pakistan's efforts in fighting Covid-19, but warned that recent statistics suggest its current strategy was not paying off. It recommended the government adopt a 2-week-on, 2-week-off lockdown, as it offered the most chance of continuing economic activities while ensuring public health.

There is need to abide by the rules and regulations settled by WHO otherwise Health of People of Pakistan may remain at risk for coming 2 months.

Acknowledgement. I am Thankful to my Institute University of Central Punjab, Lahore Pakistan for providing me support for conducting the data analysis and write-up of the manuscript.

Author Contributions. Sadia Zia coined, designed, data gathering, and wrote the article and write-up of the paper.

Funding Information. N/A

Conflict of Interest. The Author declared no-conflict of interest.

Data Availability. Data openly available in a public repository, with a permanent identifier (such as a DOI).

Supplementary Materials. To view supplementary material for this article, please visit http://dx.doi.org/10.1017/exp.2020.39.

\section{References}

Ministry of Health, Government of Pakistan. (n.d.). http://covid.gov.pk/stats/pakistan

Primary and Secondary Health Care Department. (n.d.). https://pshealth.punjab.gov.pk/Home/ProgressReports

Cite this article: Zia S (2020). Infection to Recovery; COVID-19 in Pakistan and its Implications Experimental Results, 1, e32, 1-4. https://doi.org/10.1017/exp.2020.39 


\title{
Peer Reviews
}

\section{Reviewing editor: Prof. Martin Michaelis}

University of Kent, School of Biosciences, Canterbury, United Kingdom of Great Britain and Northern Ireland, CT2 7NJ

This article has been accepted because it is deemed to be scientifically sound, has the correct controls, has appropriate methodology and is statistically valid, and met required revisions.

doi:10.1017/exp.2020.39.pr1

Review 1: Infection to Recovery; COVID-19 in Pakistan and its Implications

Reviewer: Dr. Daishun Liu

Date of review: 10 July 2020

\begin{abstract}
(C) The Author(s), 2020. Published by Cambridge University Press This is an Open Access article, distributed under the terms of the Creative Commons Attribution licence (http://creativecommons.org/licenses/by/4.0/), which permits unrestricted re-use, distribution, and reproduction in any medium, provided the original work is properly cited.
\end{abstract}

Conflict of interest statement. Reviewer declares none

Comments to the Author: Here, I would like to thank the editor and the authors for allowing me to review this article.

\section{Score Card}

Presentation

5.0

Is the article written in clear and proper English? (30\%)

Is the data presented in the most useful manner? (40\%)

Does the paper cite relevant and related articles appropriately? (30\%)

\section{Context}

Does the abstract correctly embody the content of the article? (25\%)

Does the introduction give appropriate context? (25\%)

Is the objective of the experiment clearly defined? (25\%)

Analysis

Are the limitations of the experiment as well as the contributions of the experiment clearly outlined? $(20 \%)$ 


\section{Review 2: Infection to Recovery; COVID-19 in Pakistan and its Implications}

Reviewer: Dr. Mohamed El Kassas

Date of review: 17 July 2020

(C) The Author(s), 2020. Published by Cambridge University Press This is an Open Access article, distributed under the terms of the Creative Commons Attribution licence (http://creativecommons.org/licenses/by/4.0/), which permits unrestricted re-use, distribution, and reproduction in any medium, provided the original work is properly cited.

Conflict of interest statement. I declare no competing interest

Comments to the Author: The authors tried in this manuscript to discuss the situation of COVID-19 in Pakistan which is important. However; using the example of the family with inappropriate in this context. I recommend to remove this and keep the data.

\section{Score Card}

Presentation

4.0

Is the article written in clear and proper English? (30\%)

Is the data presented in the most useful manner? (40\%)

Does the paper cite relevant and related articles appropriately? (30\%)

Context

3.2

Does the title suitably represent the article? (25\%)

Does the abstract correctly embody the content of the article? (25\%)

Does the introduction give appropriate context? (25\%)

Is the objective of the experiment clearly defined? (25\%)
Analysis

3.6

Does the discussion adequately interpret the results presented? (40\%)

Is the conclusion consistent with the results and discussion? (40\%)

Are the limitations of the experiment as well as the contributions of the experiment clearly outlined? $(20 \%)$ 